\title{
The four components to combine flood protection with other functions
}

\author{
Richard J.C. Marijnissen ${ }^{1 *}$, Matthijs Kok ${ }^{2}$, Carolien Kroeze ${ }^{1}$ \& Jantsje M. van Loon-Steensma ${ }^{1,2}$ \\ ${ }^{1}$ Water Systems and Global Change group, Wageningen University \& Research, P.O. Box 47, 6700 AA Wageningen, the Netherlands \\ ${ }^{2}$ Hydraulic Engineering, Delft University of Technology, P.O. Box 5048, 2600 GA Delft, the Netherlands
}

\begin{abstract}
Multifunctional flood defence systems combine flood defence functions with elements in the flood protection zone that fulfil other functions like nature, housing or agriculture. The wide range in possible combinations of dike configurations and functions complicates a unified approach for designing and assessing multifunctional flood defences. The aim of this paper is to describe how multifunctional elements and flood protection can be linked in an integrated design. We analyse three cases: a typical Dutch riverine dike, the Wide Green Dike in the Dollard estuary, and the Double Dike project at Eemshaven-Delfzijl. These cases include additional functions ranging from nature, to clay mining, and saline agriculture among others. From these examples a framework connecting multifunctional use to flood risk was developed. Such other functions affect flood risk by interacting with four general components of the flood defence: 1) the foreshore 2) the geometry of the flood defence system, 3) the (state of) materials used for flood protection elements, and 4) objects in, on or near the flood protection zone. For the first three components assessment procedures for monofunctional dikes can be followed. Objects require new procedures as these can introduce new modes of failure, directly interact with the hydraulic loads and generate new loads.
\end{abstract}

\section{Introduction}

Many of the world's deltas face an increasing risk of flooding by a combination of a rising sea-level and socioeconomic growth. To protect people and assets within flood prone areas from flooding, coastlines and rivers are lined with a network of flood protection measures such as dikes, levees and dams. In urbanised areas in particular, space required for developing or adapting flood protection measures is contested by other needs like e.g. housing, recreation or nature conservation. One solution is to combine the flood protection measures with other uses in so-called multifunctional flood defences (MFFDs).

Lack of space for flood protection is not the only driver for MFFDs. Some added functions can synergise with the flood protection function. The idea to utilise the hydraulic and morphological processes of coastal and estuarine ecosystems (e.g. mud and sand banks, salt-marshes, mangroves and oyster reefs) to decrease the loads on flood protection measures has been gaining traction (Borsje et al., 2011). These hybrid and nature-based flood defences have been proposed as alternatives to traditional measures by many studies (Sutton-Grier, Wowk, \& Bamford, 2015; Temmerman et al., 2013; van Wesenbeeck et al., 2014). In urban areas structures like parking garages are integrated with the flood defence to support the structure (Stalenberg, 2013).

On the other hand, some functions can diminish the safety of a flood defence. This may be the case with woody vegetation penetrating the protective clay layer in front of the dike, increasing the risk of water seeping below the dike (Zanetti, Vennetier, Mériaux, Royet, \& Provansal, 2011). In other cases functions may only affect the flood defence in rare circumstances, e.g. when a pipeline breaks resulting in damage to the dike. Determining whether a flood protection measure is sufficient to meet local flood safety standards requires identifying the modes of failure and estimating the probability of the conditions leading up to that failure (Kok, Jongejan, Nieuwjaar, \& Tanczos, 2017). MFFDs are more complex to assess as other functions may interact with the modes of failure, both directly or indirectly, or introduce entirely new ones.

A conservative approach is to make a robust design with larger dimensions and stricter safety criteria than is necessary for a monofunctional dike (van Loon-Steensma \& Vellinga, 2014). It is argued that such robust multifunctional designs, while more costly, are preferable over a leaner MFFD. Firstly, robust MFFDs allow for greater flexibility in functions it can facilitate. Secondly, the larger dimensions allow the flood defence to better cope with unforeseen adverse processes related to the other functions without an immediate reinforcement.

Another approach is to probabilistically evaluate the effect of functions on the safety of the MFFD (Marijnissen, Kok, Kroeze, \& van Loon-Steensma, 2019). In this approach a MFFD can be made larger or smaller than a monofunctional defence depending on the likelihood of the function positively or negatively affecting the

\footnotetext{
* Corresponding author: richard.marijnissen@wur.nl DOI 10.3311/FLOODRisk2020.12.3
} 
probability of a failure mechanism. An advantage of this approach is that synergies between functions and flood defences can be exploited to more efficiently reinforce a flood defence. Furthermore, flood defences can be optimized for specific other uses. However, it requires that risks and processes are understood well enough to incorporate the functions in a flood defence design, especially under extreme conditions. With continued scientific research these processes are becoming more suitable for incorporating in risk assessments, as is currently the case for salt marshes on foreshores of flood defences (Marijnissen, Esselink, Kok, Kroeze, \& van Loon-Steensma, 2020a; Marijnissen, Kok, Kroeze, \& van Loon-Steensma, 2020b; Vuik, Jonkman, Borsje, \& Suzuki, 2016).

Clearly, assessment and design principles for MFFDs are already available. While such principles are useful, it is helpful to see how such principles are translated into actual dike dimensions. The aim of this paper is therefore to describe how multifunctional elements and flood protection are linked through the design of a flood protection measure.

\section{Assessing the safety of flood defences}

The introduction of any function must not lead to an unacceptably high probability of failure of the flood defence. The most common modes of failure of a flood defence are presented in Table 1. Assessing the probability failure of these mechanisms can vary from empirical relations based on tests, to numerical simulations (Table 1).

Regardless of the methods used, at the core of any safety assessment is a limit state function in the form of:

$$
Z=R-S \text {, }
$$

where $Z<0$ denotes failure as the soliciting loads $(S)$ are greater than the resistance $(R)$ of the flood defence. Both $S$ and $R$ are composed of uncertain factors and hence $Z$ will be uncertain. These uncertainties are modelled as probability density functions (PDFs). The goal of a designer of a flood defence is to ensure that the probability of $Z<0$ remains below an acceptable level.

The loads are most often hydraulic loads like water level, wave characteristics, and the duration of the storm

\begin{tabular}{|c|c|c|}
\hline Failure mechanism & Description & Assessment Methods in the Dutch assessment procedures \\
\hline $\begin{array}{l}\text { Overflow and } \\
\text { overtopping }\end{array}$ & $\begin{array}{l}\text { Flow of water across the dike crest } \\
\text { and inner slope }\end{array}$ & $\begin{array}{l}\text { Wave overtopping: van der Meer et al. (2016), TAW (2002), } \\
\text { Waal (1999) } \\
\text { Overtopping resistance: Critical overtopping discharge, } \\
\text { (Ministerie van Infrastructuur en Milieu, 2016) }\end{array}$ \\
\hline Piping & $\begin{array}{l}\text { Excessive flow of groundwater } \\
\text { beneath the dike resulting in } \\
\text { erosion of the subsoil }\end{array}$ & $\begin{array}{l}\text { Uplift: Basic force balance (Rijkswaterstaat, 2016) } \\
\text { Heave: Empirical critical heave gradient (Rijkswaterstaat, 2016) } \\
\text { Erosion: Sellmeijer, de la Cruz, van Beek, and Knoeff (2011) }\end{array}$ \\
\hline $\begin{array}{l}\text { Macro stability inner } \\
\text { slope }\end{array}$ & Sliding of the soil at the inner slope & $\begin{array}{l}\text { Basic methods: Bishop (1955), Morgenstern and Price (1965), } \\
\text { Spencer (1967), Janbu (1973), Lift- Van (2001) } \\
\text { Advanced methods: Finite elements modelling, e.g. Griffiths and } \\
\text { Fenton (2007) }\end{array}$ \\
\hline $\begin{array}{l}\text { Erosion of grass } \\
\text { revetment on outer slope }\end{array}$ & & $\begin{array}{l}\text { Empirical cumulative overload method (de Waal \& van Hoven, } \\
\text { 2015a, 2015b; Rijkswaterstaat, 2016) }\end{array}$ \\
\hline $\begin{array}{l}\text { Erosion of other type of } \\
\text { revetment on outer slope }\end{array}$ & $\begin{array}{l}\text { Damage and erosion of the } \\
\text { protective outer layer of the dike } \\
\text { by waves }\end{array}$ & $\begin{array}{ll}\text { Asphalt: } & \text { GOLFKLAP model (de Looff, 't Hart, Montauban, \& } \\
& \text { van de Ven, 2012) } \\
& \text { Empirical uplift criterion (Rijkswaterstaat, 2016) } \\
\text { Stone: } & \text { Stability under uplift: force balance (e.g. Breteler, } \\
& \text { Mourik, and Provoost (2014)) } \\
& \text { Stability against sliding: force balance } \\
& \text { (Rijkswaterstaat, 2016) } \\
& \text { Other: less influential sub-failures have been omitted } \\
& \text { from this table. }\end{array}$ \\
\hline Other & - & - \\
\hline
\end{tabular}

Table 1. The failure mechanisms and assessment methods

\begin{tabular}{|c|c|c|c|c|c|c|c|c|c|c|}
\hline & \multicolumn{6}{|c|}{ Resistance factors } & \multicolumn{4}{|c|}{ Load factors } \\
\hline & \multicolumn{3}{|c|}{ Dike geometry } & \multicolumn{2}{|c|}{ Dike composition } & & \multicolumn{3}{|c|}{ Hydraulic loads } & \multirow{2}{*}{$\begin{array}{l}\text { Other } \\
\text { External } \\
\text { loads }\end{array}$} \\
\hline & $\begin{array}{l}\text { Crest } \\
\text { height }\end{array}$ & $\begin{array}{l}\text { Berm } \\
\text { /dike } \\
\text { width }\end{array}$ & $\begin{array}{l}\text { Dike } \\
\text { slope }\end{array}$ & $\begin{array}{l}\text { Revetment } \\
\text { material }\end{array}$ & $\begin{array}{l}\text { Core } \\
\text { material(s) }\end{array}$ & Subsoil & $\begin{array}{l}\text { Water } \\
\text { level }\end{array}$ & $\begin{array}{l}\text { Wave } \\
\text { action }\end{array}$ & $\begin{array}{l}\text { Event } \\
\text { duration }\end{array}$ & \\
\hline $\begin{array}{l}\text { Overflow \& } \\
\text { Overtopping }\end{array}$ & $\mathrm{X}$ & $\mathrm{X}$ & $\mathrm{X}$ & $\mathrm{X}$ & $(\mathrm{X})^{*}$ & & $\mathrm{X}$ & $\mathrm{X}$ & $(\mathrm{X})^{*}$ & \\
\hline Piping & & $\mathrm{X}$ & & & & $X$ & $X$ & & $(\mathrm{X})^{*}$ & \\
\hline $\begin{array}{l}\text { Macro } \\
\text { stability }\end{array}$ & & $\mathrm{X}$ & $\mathrm{X}$ & $\mathrm{X}$ & $\mathrm{X}$ & $\mathrm{X}$ & $\mathrm{X}$ & & $(\mathrm{X})^{*}$ & $\mathrm{X}$ \\
\hline $\begin{array}{l}\text { Revetment } \\
\text { failure }\end{array}$ & & & $\mathrm{X}$ & $\mathrm{X}$ & $\mathrm{X}$ & & $\mathrm{X}$ & $\mathrm{X}$ & $\mathrm{X}$ & \\
\hline
\end{tabular}

Table 2. Relation between dike elements, storm conditions, and failure mechanisms. A " $\mathrm{X}$ " denotes a connection. 
or high water (Table 2). Some loads are subject to the design itself (e.g. the external weight of a structure). The resistance to the loads must be delivered by the different elements of the flood defence. The flood defence itself can be decomposed in: the shape (height, width, slope, etc.), and the material composition (sand, clay, asphalt, etc.). The dike composition is further broken down based on its location:

- the revetment, i.e. the outer shell,

- the core,

- and the soil beneath the dike including features like sheet pile walls.

The relations between the components of the dike and the failure mechanisms are presented in Table 2. For an additional function in a MFFD to affect its safety it needs to interact with the dike geometry, dike composition or the loads (the columns in Table 2). We look at three cases to explore how these interactions influence dike designs in practice.

\section{Examples of additional functions affecting dike designs}

\subsection{Typical Dutch river dike}

The first case is a typical Dutch riverine dike. Some functions appear so frequent that assessment methods for those uses are present in the Dutch legal dike assessment tools (WBI2017). We combined these into one "prototypical" multifunctional river dike (Figure 1).

In the legal assessment framework other uses are not mentioned explicitly, but are represented by non-water retaining objects (NWOs). The functions covered are: nature in the form of woody vegetation, infrastructure in the form of pipelines, and structures for e.g. housing. An exception is transportation. The loads on the flood defence by cars and trucks need to be considered in stability calculations if they can plausibly be expected on the dike in flood scenarios. Other functions, e.g. recreation, are often not considered to have an effect on safety.

According to the WBI guidelines (Rijkswaterstaat, 2016), the dike must be dimensioned such that the objects do not interfere with the minimal profile needed to retain water under extreme conditions unless the safety of a MFFD can be demonstrated with tailored studies. In Figure 1 for example, the subsoil is penetrated by the roots of vegetation. This poses a risk of water seeping into a sandy layer below the dike and result in piping beneath the flood defences. Similarly, a pipeline can result in local erosion and therefore the soil around it should be treated as compromised in a high water event. This affects the stability of the surrounding soil (macro stability) and is vulnerable to further erosion by overtopping water. Similarly, both the house and the road should be treated as applying maximum loads to the flood defence. However, in cases where those loads aid in stabilizing the soil, the critical situation in which no house or traffic is present should be assessed (Rijkswaterstaat, 2016).

The basic method suggested in the WBI is to pad the dike shape, such that these functions no longer interfere with the minimal required profile, e.g. adding a stability or piping berm. Alternatively the composition of the dike itself can be altered to reduce the required profile, e.g. adding a sheet pile wall to support the soil.

\subsection{Wide Green Dike at the Dollard}

The Wide Green Dike is located in the Dutch Dollard region of the Ems estuary in the Wadden Sea near the border between Germany and the Netherlands. It features a shallow slope of approximately 1:7 at the seaward side (hence "wide") with only a grass revetment (hence "green") (see Figure 2) (van Loon-Steensma, Schelfhout, \& Vellinga, 2014). The grass revetment extends into the extensive Dollard salt marshes. Currently it is being developed as a pilot, but will be implemented for all dike sections in the Dollard when successful.

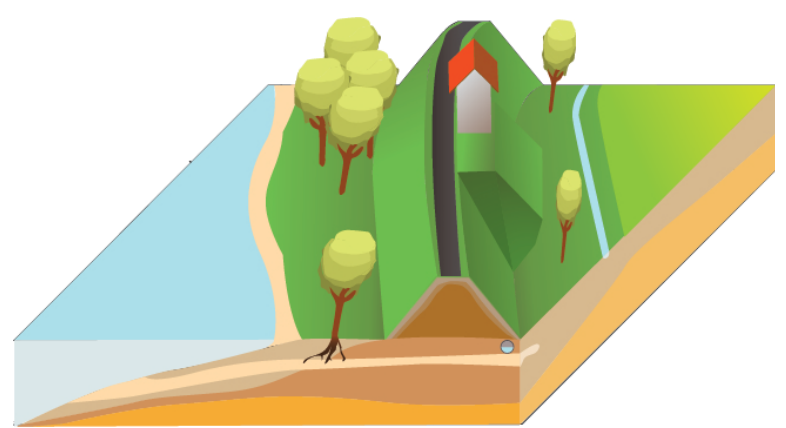

Figure 1. Example of a river dike with common multifunctional elements like trees, a house and a pipeline in the inner dike toe.

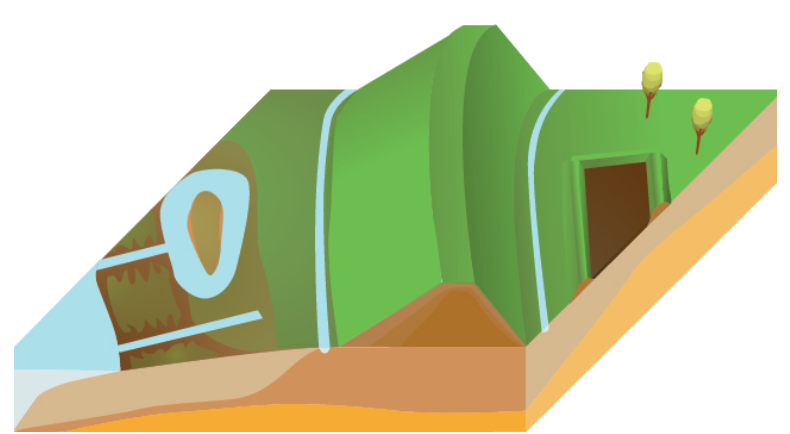

Figure 2. The wide green dike, left of the dike is the marsh with the extraction pit around the bird island. Right of the dike there is an area to process and store extracted clay.

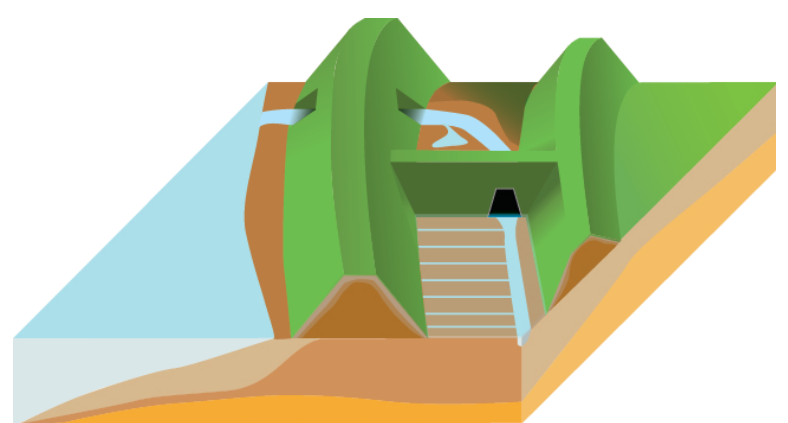

Figure 3. The double dike. At the top a section is dedicated to nature and clay extraction and the bottom is designated for agri- and aquaculture. Each section is connected by structures through the dike. 
The concept is to reinforce the dike with clay extracted locally from borrowing pits in the salt marsh. The clay is first processed and dried before being applied on the dike. Aside from providing material for the dike, the borrowing pits serve two additional purposes: to create an additional sediment sink in the turbid Dollard and thus improve water quality, and to create a breeding island for birds. The current borrowing pit is expected to be refilled within 20 years, after which it can be re-excavated (Marijnissen et al., 2020a). While clay pits do re-create pioneer marsh vegetation (Vöge, Reiss, \& Kröncke, 2008), large scale clay extraction should be managed to avoid trade-offs for nature values, further permanent marsh loss or impede the marsh's capacity to accrete in response to sea-level rise.

In this project the dike design was affected by the use of local clay on the outer slope. The weaker outer revetment was strengthened by a shallower outer slope and thick clay layer. In contrast to the functions presented in section 3.1, in this case the natural values of the marsh synergize with flood protection. While the influence of a marsh on wave loads is independent of the dike, the design change of the outer slope integrates the sediment accumulation properties of the marsh with the dike.

\subsection{Double Dike at Delfzijl}

The Double Dike at Delfzijl is, like the Wide Green Dike, a pilot in the Ems estuary in the Dutch Wadden Sea. Two parallel dikes will be constructed and the area in between can be flooded with the tide through a culvert in the first dike (Figure 3). During storm conditions the culvert will be closed.

The area between the dikes will be used for trapping silt in the Ems estuary (similar to the Wide Green Dike), nature development, aquaculture, and saline agriculture. This area is divided in two sections. The first section is connected to the estuary by a culvert. In this area suspended sediment from the estuary is allowed to settle, enabling the formation of a marsh system and the collection of clay. The second section is connected to the first section through an inlet structure. Because part of the suspended sediment has already settled in the first area, the water will be less turbid and more suitable for aquaculture and agriculture.

The additional functions in this case study are thus placed between two flood protection structures and supported by an inlet structure in the dike. The Double Dike at Delfzijl has a taller seaward dike and a lower landward dike, hence flood protection is primarily provided by the seaward dike. Because a culvert will be made in the seaward dike, an additional failure mechanism is introduced, i.e. failure to close the culvert. In cases of non-closure of the culvert, excessive overtopping of the first dike, or a breach of the first dike, additional flood protection will be provided by the second dike. As a result, loads on the landward dike are conditional on a failure at the seaward dike. After determining those failure probabilities and accompanying loads on the second dike, a new set of hydraulic boundary conditions is derived from which the probabilistic assessment methods (see Section 2) can be used to assess the safety of the entire flood protection system (Marijnissen, Kok, Kroeze, \& van LoonSteensma, Submitted).

The multifunctional use of this dike system will affect the design of this flood defence system through the addition of a culvert and a second dike. In order to provide the same safety as a regular monofunctional dike without culvert, the additional risk introduced by the culvert must be compensated by the landward dike when the seaward dike fails. Since the landward dike is lower than the seaward dike, it is unlikely the former can resist a flood in the event of a non-closure or full dike breach. Hence, strict reliability requirements are placed on the culvert system which is still being designed at the time of writing.

\section{General framework for multifunctional dike design}

\subsection{Framework for linking multifunctional design to flood risk}

To incorporate multifunctional use in a flood defence several components may be added or changed. These correspond with the components already identified in Table 2, but with the addition of the foreshore. This was motivated by both the Wide Green Dike and Double Dike cases. Most of the multifunctionality of the Wide Green Dike was derived from the foreshore of the system, rather than any multifunctional use of the dike itself. Foreshore elevation (e.g. by marsh accretion) and composition (e.g. the higher roughness of a marsh substrate) can work in

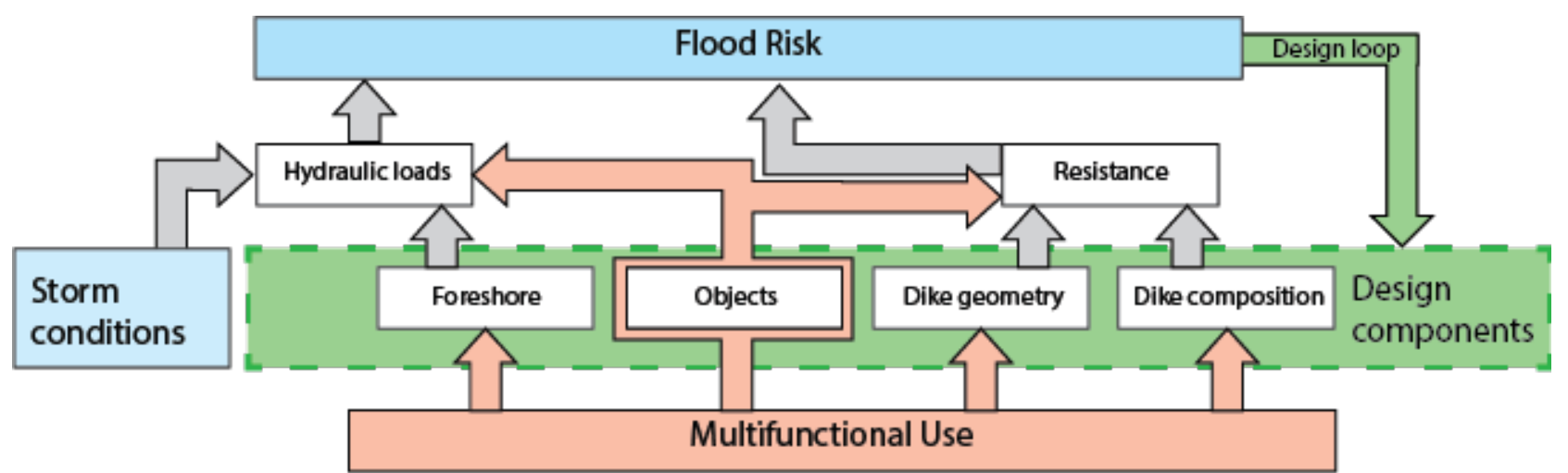

Figure 4. The connection between multifunctional use, flood risk, and the design choices within a flood defence. Orange arrows denote the influence of multifunctional use, the green block contains design elements, and the blue blocks represents flood conditions. 
conjunction to decrease loads (e.g. through wave breaking and friction) (Marijnissen et al., 2020b). The case of the Double Dike requires a shift in perspective, as the first dikes can also be perceived as a foreshore to the final landward dike (Marijnissen et al., Submitted).

Allowing multifunctional use by changes in dike geometry has been the default approach as suggested by van Loon-Steensma and Vellinga (2014). This approach has been used for the concepts of delta dike, unbreachable dike, and the super dike (de Moel et al., 2010; Knoeff \& Ellen, 2011; Nakamura, 2016; Silva \& van Velzen, 2008). Also in the case-study of the Wide Green Dike, multifunctional use did affect the dike geometry.

Because of the choice to preserve the landscape value of a green grass dike and re-use clay extracted from the estuary, the dike's slope was made less steep to increase the resistance of the dike to wave impacts (Marijnissen et al., 2020a). Thus, multifunctional use directed the design of the dike's geometry.

Dike composition is another way to introduce multifunctional use. The grass cover on the Wide Green Dike for landscape values is one such example. A similar concept in which the dike's ecological value is enhanced by flowers or herbs on its outer cover, is another example. The erosion-resistance of the dike cover is primarily governed by the root density and the overall root depth (Scheres \& Schüttrumpf, 2020; Vannoppen, Poesen, Peeters, De Baets, \& Vandevoorde, 2016). Introducing additional vegetation species to improve the ecological value of the dike therefore has a direct influence on the dike design. Another example of multifunctional design is the integration of a house with the flood wall (van Veelen, Voorendt, and van der Zwet (2015).

Objects that do not fulfil a flood protection function on dikes have always been present, e.g. fences, trees, houses, cables, pipes, pavements, roads, etc. The variety in objects quite large, but for the classification in this paper we only consider objects fixed to the dike that do not contribute to flood protection but can affect or introduce modes of failure.

\subsection{Implementation of multifunctionality in dike safety assessments}

The four types of multifunctional design components require each a different implementation in the risk framework. Figure 5 presents an extended assessment framework suitable for dikes with multifunctional components.

Foreshore components reduce the hydraulic loads before the flood defence is reached (Figure 5). Tools and models (e.g. SWAN, X-Beach, Delft-3D) are already present to simulate the behaviour of waves and storm surges across foreshores of different compositions. Often the presence of natural features on foreshores like marshes are not included, as relying on these features for flood protection lacks certainty about their presence under changing conditions. Inclusion of these natural features is limited by the willingness and legal limitations of preserving nature areas for flood protection .
Parallel flood defences also fall within the category of foreshores (Figure 5). The front dike in the system reduces hydraulic loads on the landward dike by reducing the probability of waves and surges at the final landward defence (Marijnissen et al., Submitted). As such it fulfils a similar function as a foreshore, albeit to a much larger degree and through different processes. To determine the erosion and subsequent flows over/through the first defence, complex models are required and makes the assessment of parallel defences challenging. However, once there is accounted for reductions in hydraulic loads, the assessment process can proceed as for monofunctional dikes (Marijnissen et al., Submitted).

Dike geometry and dike composition are integrated in the resistance of a flood defence and are already included in any safety assessment (Figure 5). Geometry in particular, like changes in a slope, are parameters that can already be varied in most design formulas and approaches. Incorporating changes in dike composition can be more challenging if the relevant material properties (e.g. the erosion of marsh clay in the Wide Green Dike case) are uncertain. However, such uncertainties can be overcome by experimentally testing the properties or by employing measures to ensure quality standards are met. Alternatively, a probabilistic assessment can be made with the larger uncertainties in mind. Objects embedded into a material can also be considered as a change in the material property. For example, Aguilar-López, Warmink, Schielen, and Hulscher (2018) demonstrate a pipeline below a dike can be conceived as a change in hydraulic conductivity of the subsoil rather than as an object within the assessment of the piping failure mechanism.

Objects can possess their own interactions with the hydraulic loads to decrease the resistance of the system (Marijnissen et al., 2019). These interactions were observed in the treatment of roads (with traffic) and structures in the first example of a proto-typical river dike. Additional loads were applied to the dike directly in conjunction with the hydraulic loads (Rijkswaterstaat, 2019). The interactions between objects, hydraulic loads, and resistance greatly depend on the specifics of the object, how it is used during a high water event, and the particular failure mechanisms the object interacts with. Therefore no universal safety strategy could be identified for this type of design component. It is recommended to select scenarios for the state of the object during a high water event (including a worst-case one), and attribute probabilities to each scenario (Figure 5). These scenarios are then evaluated for the relevant failure mechanisms and combined into a single probability with fragility curves (Marijnissen et al., 2019).

\section{Discussion}

Many dikes are already multifunctional. They may serve a transportation function by a road on top or its slope may be part of a nature reserve. This was covered by the "prototypical" Dutch dike example in this paper. Both traditional assessment standards (Ministerie van Verkeer en Waterstaat, 2007; Rijkswaterstaat, 2016) and other 
A)

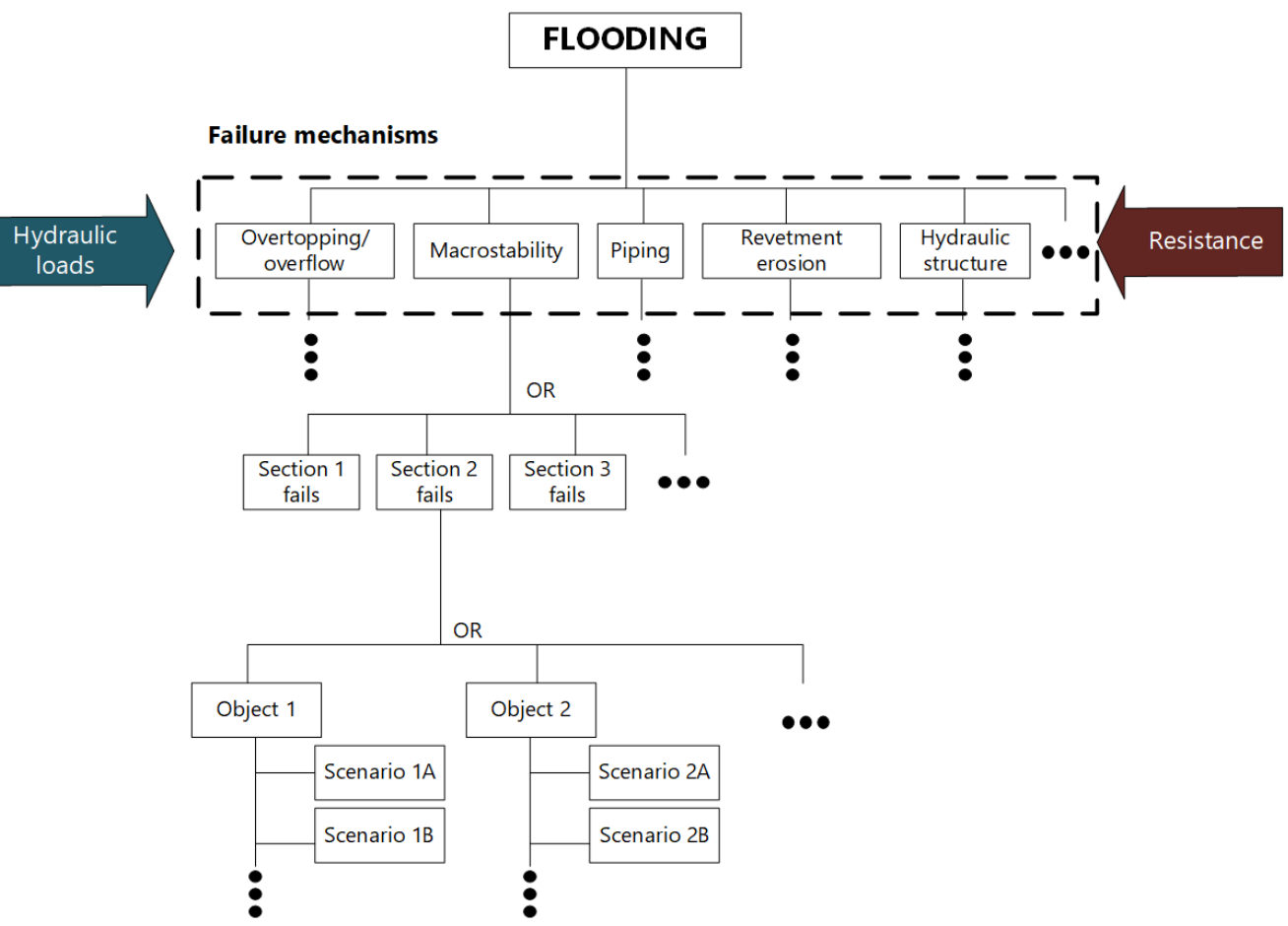

B)

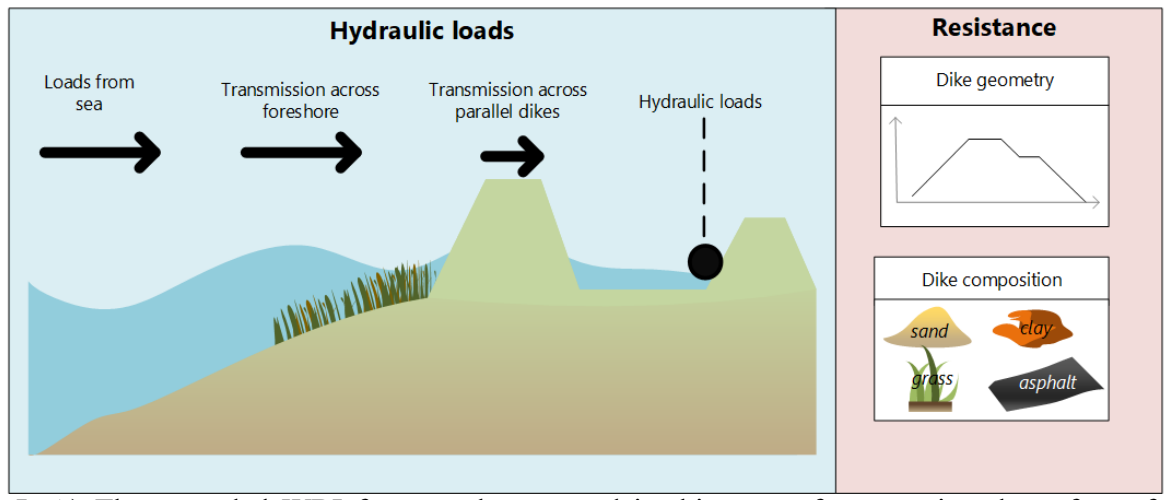

Figure 5. A) The extended WBI framework proposed in this paper for assessing the safety of flood defences to allow for multifunctional components. B) The hydraulic loads and resistance factors that influence the probability of failure for a failure mechanism.

literature (van Loon-Steensma \& Vellinga, 2014) assert a negative effect of functions for a design of a flood defence to ensure a safe design. This is understandable, as the majority of examples of functions do not provide direct benefits for flood protection or those benefits are uncertain (van Loon-Steensma \& Kok, 2016). As a consequence, however, defences will not gain any safety benefits from other functions in this approach.

Voorendt, Vrijling, and Voortman (2017) distinguish different levels of functional integration based on the overlap of functions with water structural elements of the flood defence. Voorendt (2017) identified 8 types of structural elements multifunctional for MFFDs. The underlying idea is that multifunctional design can only improve safety if an element required for multifunctional use can fulfil the function of a structural element of a flood defence (e.g. the walls of a parking garage that also serve at the same time as retaining walls). However, these types of functions were not included in our cases, as these are more common in urban settings (Stalenberg, 2013; Voorendt et al., 2017). This view of multifunctionality ties in neatly with the dike composition elements identified in this paper, where material or composition design choices are motivated by multifunctional use.

The frameworks for MFFDs so far had only a limited scope of multifunctionality of dike design. A growing body of scientific literature is starting to connect natural processes in foreshore ecosystems like coral reefs, salt marshes, and mangroves, to flood risk mitigation (Borsje et al., 2011; Ferrario et al., 2014; Guannel, Arkema, Ruggiero, \& Verutes, 2016; Vuik et al., 2016). Such connections are missed when the flood defence structure is very narrowly demarcated, and does for instance not include foreshores. The cases in this study furthermore highlight that multifunctionality can be integrated across the entire flood protection zone, from the foreshore until multiple lines of flood defences. The framework presented in this paper thus allows for a wider application of MFFDs than other studies had so far.

While the links between multifunctional use and flood protection cover a wider range of practical applications, it does not consider the benefits of a flexible design over a 
static one. This may further alter the design choices. Studies have suggested natural elements can add flexibility and resilience to regular defences under a changing climate (van Slobbe et al., 2013; van Wesenbeeck et al., 2014). Building with nature measures like the suppletion of sand or silt on marsh foreshores are such examples (Baptist et al., 2019; Stive et al., 2013). Under favourable conditions, natural systems may even adapt to a changing environment without maintenance. Because safety assessments are conducted for a single moment in time, the flexibility and maintenance aspects is not captured if designs are made only on the basis of assessment rules. In the long term, not accounting for these leads to less cost-optimal designs for both monofunctional and multifunctional dikes (Anvarifar et al., 2017).

Finally, it is important to stress that flood protection and costs are never the only factors governing the choice for a multifunctional flood defence. A proper integration of other functions will add other values to the area by for example various ecosystem services by nature, food by aquaculture, etc.. These benefits need to be accounted for in the costs of alternative safe dike designs.

\section{Conclusions}

Multifunctional flood defences are of growing interest to protect deltas from floods. In this paper we introduced a broader framework to tune dike-design elements to ensure the safety of a multifunctional flood defence.

Three examples of multifunctional dike design concepts were discussed, from which four categories of multifunctional design components were identified: 1) foreshore, 2) dike geometry, 3) dike composition, and 4) dike objects. Multifunctional foreshore elements affect hydraulic loads directly and can be incorporated in dike assessments via accounting for these changes. Similarly, existing dike assessment procedures can be followed when additional functions affect the geometry of the flood defence and/or the choice of materials used in dike elements. When additional functions are facilitated by objects, dike assessments need to be adapted. New failure mechanisms and the direct interactions between the object and the loads on the flood defence must be incorporated to ensure a safe design.

Designs of multifunctional flood defences will vary across different environments and function combinations. Nevertheless, understanding the connections between functions and design choices for flood defences will allow for a wider and more effective implementation of such multifunctional defences.

\section{References}

1. Aguilar-López, J. P., J. J. Warmink, R. M. J. Schielen, and S. J. M. H. Hulscher. (2018). Piping erosion safety assessment of flood defences founded over sewer pipes. European Journal of Environmental and Civil Engineering, 22(6), 707-735. doi:10.1080/19648189.2016.1217793

2. Anvarifar, F., M. Kok, W. Thissen, C. Zevenbergen, D. Osmanoglou, and B. R.
Tangabi. (2017). Cost-effectiveness analysis of reinforcement strategies for (multifunctional) flood defences. International Journal of Critical Infrastructures, $\quad \mathbf{1 3 ( 4 ) ,}$ 297-328. doi:10.1504/IJCIS.2017.089240

3. Baptist, M. J., T. Gerkema, B. C. van Prooijen, D. S. van Maren, M. van Regteren, K. Schulz, I. Colosimo, J. Vroom, T. van Kessel, B. Grasmeijer, P. Willemsen, K. Elschot, A. V. de Groot, J. Cleveringa, E. M. M. van Eekelen, F. Schuurman, H. J. de Lange, and M. E. B. van Puijenbroek. (2019). Beneficial use of dredged sediment to enhance salt marsh development by applying a 'Mud Motor'. Ecological Engineering, 127, 312-323. doi:10.1016/j.ecoleng.2018.11.019

4. Bishop, A. W. (1955). The use of the slip circle in the stability analysis of slopes. Géotechnique, 5(1), 7-17. doi:10.1680/geot.1955.5.1.7

5. Borsje, B. W., B. K. van Wesenbeeck, F. Dekker, P. Paalvast, T. J. Bouma, M. M. van Katwijk, and M. B. de Vries. (2011). How ecological engineering can serve in coastal protection. Ecological Engineering, 37(2), 113-122. doi:10.1016/j.ecoleng.2010.11.027

6. Breteler, M. K., G. Mourik, and Y. Provoost. (2014). Stability of placed block revetments in the wave run-up zone. Coastal Engineering Proceedings, $\quad \mathbf{1 ( 3 4 )}$, doi:10.9753/icce.v34.structures.24

7. de Looff, A. K., R. 't Hart, K. Montauban, and M. F. C. van de Ven. (2012). Golfklap a model to determine the impact of waves on dike structures with an asphaltic concrete layer. In Coastal Engineering 2006 (pp. 5106-5115): World Scientific Publishing Company.10.1142/9789812709554_0427

8. de Moel, H., J. Beijersbergen, F. van den Berg, J. de Goei, R. C. Koch, A. R. Koelewijn, J. M. van Loon-Steensma, I. M. Molenaar, J. Steenbergen-Kajabová, H. Schelfhout, S. Versluis, and A. M. Zantinge. (2010). De Klimaatdijk in de Praktijk : gebiedsspecifiek onderzoek naar nieuwe klimaatbestendige dijkverbeteringsalternatieven langs de Nederrijn en Lek. In H. de Moel (Ed.). Retrieved from http://publicaties.minienm.nl/documenten/deklimaatdijk-in-de-praktijk-gebiedsspecifiekonderzoek-naar-nieuwe-klimaatbestendigedijkverbeteringsalternatieven-langs-denederrijn-en-lek Retrieved http://publicaties.minienm.nl/documenten/deklimaatdijk-in-de-praktijk-gebiedsspecifiekonderzoek-naar-nieuwe-klimaatbestendigedijkverbeteringsalternatieven-langs-denederrijn-en-lek

9. de Waal, H., and A. van Hoven. (2015a). Failure Mechanism Module Grass Wave Impact Zone: Requirements and Functional Design Deltares, Delft, Netherlannds (1220043-002-HYE-0025).

10. de Waal, H., and A. van Hoven. (2015b). Failure Mechanism Module Grass Wave Runup Zone: 
Requirements and Functional Design Deltares, Delft, Netherlannds (1220043-002-HYE-0004).

11. Ferrario, F., M. W. Beck, C. D. Storlazzi, F. Micheli, C. C. Shepard, and L. Airoldi. (2014). The effectiveness of coral reefs for coastal hazard risk reduction and adaptation. Nature Communications, $\quad$ 5(1), 3794. doi:10.1038/ncomms4794

12. Griffiths, D. V., and G. A. Fenton. (2007). The Random Finite Element Method (RFEM) in Slope Stability Analysis. In Probabilistic Methods in Geotechnical Engineering (pp. 317346). Vienna: Springer Vienna.doi:10.1007/9783-211-73366-0_14

13. Guannel, G., K. Arkema, P. Ruggiero, and G. Verutes. (2016). The power of three: coral reefs, seagrasses and mangroves protect coastal regions and increase their resilience. PloS one, 11(7). doi:10.1371/journal.pone.0158094

14. Janbu, N. (1973). Slope stability computations. In E. Hirschfield \& S. Poulos (Eds.), Embankment Dam Engineering (Casagrande Memorial Volume) (pp. 47-86). New York: John Wiley

15. Knoeff, H., and G. J. Ellen. (2011). Verkenning deltadijken Deltares, (1204259-000-ZWS$0004)$.

16. Kok, M., R. Jongejan, M. Nieuwjaar, and I. Tanczos. (2017). Fundamentals of flood protection. Retrieved from https://www.enwinfo.nl/images/pdf/Grondslagen /GrondslagenEN-lowresspread3-v.3.pdf

17. Marijnissen, R. J. C., P. Esselink, M. Kok, C. Kroeze, and J. M. van Loon-Steensma. (2020a). How natural processes contribute to flood protection - A sustainable adaptation scheme for a wide green dike. Science of The Total Environment, 739, $139698 . \quad$ doi: 10.1016/j.scitotenv.2020.139698

18. Marijnissen, R. J. C., M. Kok, C. Kroeze, and J. M. van Loon-Steensma. (2019). Re-evaluating safety risks of multifunctional dikes with a probabilistic risk framework. Natural Hazards and Earth System Sciences, 19(4), 737-756. doi:10.5194/nhess-19-737-2019

19. Marijnissen, R. J. C., M. Kok, C. Kroeze, and J. M. van Loon-Steensma. (2020b). The Sensitivity of a Dike-Marsh System to Sea-Level Rise-A Model-Based Exploration Journal of Marine Science and Engineering, 8(1), 42. doi:10.3390/jmse8010042

20. Marijnissen, R. J. C., M. Kok, C. Kroeze, and J. M. van Loon-Steensma. (Submitted). Flood risk reduction by parallel flood defences in a multifunctional flood protection zone Coastal Engineering, $\mathbf{x}(\mathbf{x}), \mathbf{x x}$.

21. Ministerie van Infrastructuur en Milieu. (2016). Schematiseringshandleiding grasbekleding. Retrieved from: https://www.helpdeskwater.nl/onderwerpen/wat erveiligheid/primaire/beoordelen-wbi/producten$\underline{\mathrm{wbi}}$
22. Ministerie van Verkeer en Waterstaat. (2007). Voorschrift Toetsen op Veiligheid Primaire Waterkeringen Ministerie van Verkeer en Waterstaat, Delft, the Netherlands (978-90-369. 5762). Retrieved from: https://www.rijksoverheid.nl/binaries/rijksoverh eid/documenten/rapporten/2007/08/01/voorschri ft-toetsen-op-veiligheid-primaire-waterkeringenvoor-de-derde-toetsronde-20062011/vtv2006.pdf

23. Morgenstern, N. R., and V. E. Price. (1965). The Analysis of the Stability of General Slip Surfaces. Géotechnique, 15(1). doi:10.7939/R3JS9HF63

24. Nakamura, H. (2016). Possibilities of neighborhood evacuation within a district in the event of a large-scale flood in a low-lying area: A case study of Shinden district in Tokyo. E3S Web Conf., $7, \quad 19005 . \quad$ doi: $10.1051 / \mathrm{e} 3$ sconf $/ 20160719005$

25. Rijkswaterstaat. (2016). Regeling veiligheid primaire waterkeringen 2017: Bijlage III Sterkte en veiligheid Ministerie van Infrastructuur en Milieu. Retrieved from: https://www.helpdeskwater.nl/onderwerpen/wat erveiligheid/primaire/beoordelen/@,205740/regel ing-veiligheid-1/

26. Rijkswaterstaat

(2019).

Schematiseringshandleiding Macrostabiliteit; WBI 2017 Rijkswaterstaat. Retrieved from: https:/www.helpdeskwater.nl/onderwerpen/wat erveiligheid/primaire/beoordelen/@,205756/sche matiseringshandleiding-macrostabiliteit/

27. Scheres, B., and H. Schüttrumpf. (2020). Investigating the Erosion Resistance of Different Vegetated Surfaces for Ecological Enhancement of Sea Dikes. Journal of Marine Science and Engineering, 8(7), 519. Retrieved from https://www.mdpi.com/2077-1312/8/7/519

28. Sellmeijer, H., J. L. de la Cruz, V. M. van Beek, and H. Knoeff. (2011). Fine-tuning of the backward erosion piping model through smallscale, medium-scale and IJkdijk experiments. European Journal of Environmental and Civil Engineering, $\quad \mathbf{1 5 ( 8 ) ,} \quad 1139-1154$. doi:10.1080/19648189.2011.9714845

29. Silva, W., and E. van Velzen. (2008). De dijk van de toekomst? Quick scan doorbraakvrije dijken Rijkswaterstaat,, (2008.052). Retrieved from: http://www.rijksoverheid.nl/bestanden/document en-en-publicaties/rapporten/2008/10/01/de-dijkvan-de-toekomst-quick-scan-doorbraakvrijedijken/de-dijk-van-de-toekomst.pdf

30. Spencer, E. (1967). A method of analysis of the stability of embankments assuming parallel interslice forces. Géotechnique, 17(1), 11-26.

31. Stalenberg, B. (2013). Innovative flood defences in highly urbanised water cities. In J. Aerts, W. Botzen, M. J. Bowman, P. J. Ward, \& P. Dircke (Eds.), Climate Adaptation and Flood Risk in Coastal Cities (pp. 145-164). London: Earthscan

32. Stive, M. J. F., M. A. de Schipper, A. P. Luijendijk, S. G. J. Aarninkhof, C. van Gelder- 
Maas, J. S. M. van Thiel de Vries, S. de Vries, M. Henriquez, S. Marx, and R. Ranasinghe. (2013). A New Alternative to Saving Our Beaches from Sea-Level Rise: The Sand Engine. Journal of Coastal Research, 29(5), 1001-1008, 1008. doi:10.2112/JCOASTRES-D-13-00070.1

33. Sutton-Grier, A. E., K. Wowk, and H. Bamford. (2015). Future of our coasts: The potential for natural and hybrid infrastructure to enhance the resilience of our coastal communities, economies and ecosystems. Environmental Science \& Policy, 51, 137-148. doi:10.1016/j.envsci.2015.04.006

34. TAW. (2002). Technisch Rapport Golfoploop en Golfoverslag bij Dijken Technische adviescomissie water, Delft (TR33). Retrieved from:

www.helpdeskwater.nl/publish/pages/144682/h2 389 technischrapportgolfoploopengolfoverslagb ijdijken.pdf

35. Temmerman, S., P. Meire, T. J. Bouma, P. M. J. Herman, T. Ysebaert, and H. J. De Vriend. (2013). Ecosystem-based coastal defence in the face of global change. Nature, 504(7478), 79-83. doi:10.1038/nature12859

36. van der Meer, J. W., N. W. H. Allsop, T. Bruce, J. De Rouck, A. Kortenhaus, T. Pullen, and B. Zanuttigh. (2016). EurOtop 2016: Manual on wave overtopping of sea defences and related structures. An overtopping manual largely based on European research, but for worldwide application. Retrieved from www.overtoppingmanual.com .

37. van Loon-Steensma, J. M., and M. Kok. (2016). Risk reduction by combining nature values with flood protection? E3S Web Conf., 7, 13003. doi:10.1051/e3sconf/20160713003

38. van Loon-Steensma, J. M., H. A. Schelfhout, and P. Vellinga. (2014). Green adaptation by innovative dike concepts along the Dutch Wadden Sea coast. Environmental Science \& Policy, 44, 108-125. doi:10.1016/j.envsci.2014.06.009

39. van Loon-Steensma, J. M., and P. Vellinga. (2014). Robust, multifunctional flood defenses in the Dutch rural riverine area. Natural Hazards and Earth System Sciences, 14(5), 1085-1098. doi:10.5194/nhess-14-1085-2014

40. Van, M. (2001). New approach for uplift induced slope failure. Paper presented at the PROCEEDINGS OF THE INTERNATIONAL CONFERENCE ON SOIL MECHANICS AND GEOTECHNICAL ENGINEERING.

41. van Slobbe, E., H. J. de Vriend, S. Aarninkhof, K. Lulofs, M. de Vries, and P. Dircke. (2013). Building with Nature: in search of resilient storm surge protection strategies. Natural Hazards, 66(3), 1461-1480. doi:10.1007/s11069-0130612-3

42. van Veelen, P., M. Voorendt, and C. van der Zwet. (2015). Design challenges of multifunctional flood defences. A comparative approach to assess spatial and structural integration. Research in Urbanism Series, 275292\%V 273. doi:10.7480/rius.3.841

43. van Wesenbeeck, B. K., J. P. M. Mulder, M. Marchand, D. J. Reed, M. B. de Vries, H. J. de Vriend, and P. M. J. Herman. (2014). Damming deltas: A practice of the past? Towards naturebased flood defenses. Estuarine, Coastal and Shelf Science, 140, 1-6. doi:10.1016/j.ecss.2013.12.031

44. Vannoppen, W., J. Poesen, P. Peeters, S. De Baets, and B. Vandevoorde. (2016). Root properties of vegetation communities and their impact on the erosion resistance of river dikes. Earth Surface Processes and Landforms, 41(14), 2038-2046. doi:10.1002/esp.3970

45. Vöge, S., H. Reiss, and I. Kröncke. (2008). Macrofauna succession in an infilling salt marsh clay pit. Senckenbergiana maritima, 38(2), 93106. doi:10.1007/BF03055284

46. Voorendt, M. Z. (2017). Chapter 5: Verification of multifunctional flood defences. In Design principles of multifunctional flood defences (Doctoral dissertation). Delft, Netherlands: TU Delft. doi: 10.4233/uuid:31ec6c27-2f53-4322ac2f-2852d58dfa05

47. Voorendt, M. Z., J. K. Vrijling, and H. G. Voortman. (2017). Structural Evaluation of Multifunctional Flood Defenses Using Generic Element Types. In Coastal Structures and Solutions to Coastal Disasters 2015 (pp. 365374). doi: 10.1061/9780784480304.039

48. Vuik, V., S. N. Jonkman, B. W. Borsje, and T. Suzuki. (2016). Nature-based flood protection: The efficiency of vegetated foreshores for reducing wave loads on coastal dikes. Coastal Engineering, 116, 42-56. doi:10.1016/j.coastaleng.2016.06.001

49. Waal, J. P. d. (1999). Deelrapport 9: Modellering dammen, voorlanden en golfoploop. In Achtergronden hydraulische belastingen dijken IJsselmeergebied (pp. 50): Lelystad : RIZA

50. Zanetti, C., M. Vennetier, P. Mériaux, P. Royet, and M. Provansal. (2011). Managing woody vegetation on earth dikes: Risks assessment and maintenance solutions. Procedia Environmental Sciences, 9 (Supplement C), 196-200. doi:10.1016/j.proenv.2011.11.030 